\title{
Presence of Biofilms in the Lacrimal Sac Mucosa
}

\author{
Lakrimal Kese Mukozasında Biyofilm Varlı̆̆ı
}

\author{
Melike KOŞARSOY, ${ }^{a}$ \\ Serdar ÖZER, ${ }^{a}$ \\ Oğuz ÖĞRETMENOĞLU, ${ }^{a}$ \\ İlkan TATAR, ${ }^{b}$ \\ Gamze ATAY, ${ }^{a}$ \\ Mehmet Cem MOCAN, ${ }^{\circ}$ \\ Taşkın YÜCEL, ${ }^{a}$ \\ Metin ÖNERCja \\ Departments of \\ aOtorhinolaryngology Head and \\ Neck Surgery, \\ ${ }^{\mathrm{b}}$ Anatomy, \\ 'Opthalmology, \\ Hacettepe University Faculty of Medicine, \\ Ankara
}

Geliş Tarihi/Received: 29.03.2013

Kabul Tarihi/Accepted: 05.06.2013

This study was presented as the fellowship thesis of Melike Koşarsoy, MD (2012-Ankara).

Yazışma Adresi/Correspondence: Serdar ÖZER

Hacettepe University Faculty of Medicine, Department of Otorhinolaryngology Head and Neck Surgery, Ankara, TÜRKIYE/TURKEY

drserdarozer@gmail.com

\begin{abstract}
Objective: The inflammation and the following fibrosis due to the bacterial colonization are thought to be the principle underlying mechanism in the development of nasolacrimal duct stenosis. The aim of this study was to investigate the presence of biofilms in the lacrimal sac mucosa of the patients with dacryostenosis. Material and Methods: This study included 15 patients with a symptom of epiphora for at least 3 months and documented dacryostenosis with a dacryocystography. Lacrimal sac mucosal specimens obtained during endoscopic dacryocystorhinostomy (DCR) were examined for the presence of biofilm formation under the scanning electron microscope. Results: The specimens were obtained from 15 patients. The mean age of 12 female and 3 male patients was 54 years. Epiphora was the main symptom and its average duration was 18 (6-36) months. We could not analyze specimen in 1 patient. We detected biofilm formation in 12 of 14 (\% 85.7) specimens. Biofilm formation was dense in 5 specimens and light in 7 specimens. Conclusion: This is the first article that documents the presence of bacterial biofilms on the lacrimal sac mucosa in the patients with dacryostenosis. This study shows the presence of biofilms in cases with dacryostenosis and interrogates its role in the etiology of chronic dacryocystitis similar to other chronic infections. Further investigations on this subject should be carried on in larger and controlled series to assure the role of biofilms in the etiology of chronic infections. New studies should also investigate whether the biofilm formation is the reason or the result of chronic infections. We believe that, control of biofilm formation in chronic infections would prevent secondary problems like the development of dacryostenosis.
\end{abstract}

Key Words: Biofilms; dacryocystitis; microscopy, electron, scanning; dacryocystorhinostomy

ÖZET Amaç: Bakteriyel kolonizasyon sonucu gelișen inflamasyon ve fibrozis, nazolakrimal kanal stenozuna yol açan temel mekanizma olarak kabul edilmektedir. Bu çalışmanın amacı, dakriostenozlu olguların lakrimal kese mukozalarında biofilm varlı̆̆ını araştırmaktır. Gereç ve Yöntemler: Bu çalışmaya en az 3 aydır epifora şikayeti olan ve dakriosistografide dakriostenoz tespit edilen 15 olgu dahil edilmiştir. Endoskopik dakriosistorinostomi sırasında elde edilen lakrimal kese mukoza örnekleri, tarayıcı elektron mikroskopide incelenerek biyofilm varlığı araştırılmıştır. Bulgular: Ortalama yaşı 54 olan 12 kadın ve 3 erkek, toplam 15 hasta çalışmaya dahil edilmiştir. Hastalarda görülen en sık semptom epifora idi ve ortalama 18 aydır mevcuttu. İncelenen 14 spesmenin 12 (\%85,7)'sinde biyofilm tespit edildi. Spesmenlerin 1 tanesinin analizi yapılamadı. Biyofilm formasyonu örneklerin 5 'inde hafif, 7'sinde ise yoğun idi. Sonuç: Bu makale dakriostenozlu hastaların lakrimal kese mukozalarında biyofilm varlı̆̆ını gösteren ilk çalışmadır. Çalışmamız dakriostenozlu olguların lakrimal keselerinde biyofilm varlığını göstermekte ve diğer kronik enfeksiyonlarda olduğu gibi kronik dakriosistit enfeksiyonu etiolojisinde de biyofilmin rol alabileceğini sorgulamaktadır. Kronik enfeksiyonların etiolojisinde biyofilmin rolünün kesin olarak gösterilebilmesi için, bu konuda daha geniş ve kontrol gruplu çalışmalar yapilmalıdır. Yeni yapılacak çalışmalar ile biyofilm formasyonunun dakriostenoz gelişimine sebep olan bir faktör mü, yoksa dakriostenoz sonucu gelişen staz sonucu olarak mı geliştiği ortaya koyulmalıdır. Biyofilm formasyonunun kontrolü ile, kronik enfeksiyonlar ve kronik enfeksiyonlara bağglı gelişen dakriostenoz gibi ikincil problemlerin önlenebileceğini düşünmekteyiz.

Anahtar Kelimeler: Biyofilmler; dakriyosistit; mikroskopi, elektron, tarama; dakriyosistorinostomi doi: 10.5336/medsci.2013-34318

Copyright $(\mathcal{C} 2013$ by Türkiye Klinikleri
Turkiye Klinikleri J Med Sci 2013;33(6):1421-5 


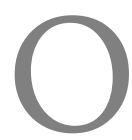

ne of the most commonly seen problems of nasolacrimal system is epiphora. Hypersecretion due to the irritation of cornea and conjunctiva or the inadequate drainage of tears are the main reasons for it. Inflammation of the nasolacrimal sac is accepted as the main reason for the development of nasolacrimal sac and duct stenosis. ${ }^{1,2}$ Triggering factors for the development of this inflammation and fibrosis in the nasolacrimal duct are not clear. Generally, colonization of infectious factors within the lacrimal sac is accepted as an initiator.

Ninety-nine percent of bacteria present in the form of biofilms. ${ }^{3}$ Many bacterial infections include biofilm formation. Biofilms are the microorganisms within one capsule. Biofilm is defined as a media that bacteria can live more easily than their planktonic (single) forms. The multilayered form of biofilm composed of extracellular matrix (ECM) is formed mostly by epoxy polysaccharide (EPS), cell debris and bacteria. ${ }^{4}$ Bacterial biofilms are 10-1000 times more resistant to antibiotic treatment when compared to the planktonic bacteria. ${ }^{5}$ They have been shown on medical instruments, and thought to be responsible especially for foreign body-related chronic infections. They are also charged with many chronic infections unrelated to biomaterials. Biofilms are thought to be related to many infections like infective endocarditis, cholangitis, tonsillitis, otitis media and chronic sinusitis. ${ }^{6} \mathrm{We}$ investigated the presence of biofilms on lacrimal sac mucosa specimens, as a possible etiological factor in the development of dacryostenosis.

\section{MATERIAL AND METHODS}

Patients who had epiphora for at least 3 months were investigated for possible nasolacrimal duct obstruction. Nasolacrimal duct patency was checked with saline irrigation by nasolacrimal lavage via inferior punctum. The patients who had obstruction at the level of lacrimal sac or nasolacrimal canal, which was confirmed with dacryocystography, were included to the study. The patients with any history of trauma to the nasolacrimal system were excluded from the study. Anterior rhinoscopy and rigid endoscopic examinations with zero degree Hopkins endoscopes were performed preoperatively to check the possible accompanying nasal pathologies. Approval for this study was obtained from the local ethics committee of our institution. Written informed consent was obtained from all participants before enrollment in the study. All clinical investigations were conducted according to the principles of Declaration of Helsinki.

All the patients underwent endoscopic dacryocystorinostomy (DCR) under general anesthesia. A mucosal ' $\mathrm{C}$ ' shape incision from anterosuperior to posteroinferior direction at the maxillary line was performed. A mucoperiosteal flap over the maxillary and lacrimal bone was elevated. After removal of bony window, complete anteroposterior extent of the medial wall of the sac was exposed. Medial wall of lacrimal sac was incised. After the identification of mucosal surface of lacrimal sac, samples were taken from the lacrimal wall involving the mucosal side with a micro-alligator punch. Canalicular silicon tubes were placed from the both punctums and tied within the nasal cavity. The surface layer of lacrimal sac mucosal samples were examined for biofilm formation by using Scanning Electron Microscopy (SEM) at the Electron Microscopy Laboratory, Department of Anatomy, Medical School, Hacettepe University. The fresh specimens were immediately fixed in $2.5 \%$ gluteraldehide solution for 24 hours. Phosphate tampon (pH: 7.4) was used to clean the specimen. After fixation with $1 \%$ osmium tetroxide, specimen was dehydrated with acetone in increasing concentrations. Specimens were placed in a sticky tape to be photographed with a Carl Zeiss EVO JO EP Scanning Electron Microscope. Presence and the intensity of the biofilm was examined. The intensity of the biofilm was graded from 0 to 2, according to the density and extension. If the biofilm occupied less than $50 \%$ of the surface area, it was accepted as a light colonization (Figure 1) and graded as grade 1 , if it occupied more than $50 \%$ of the surface area, it was accepted as a dense colonization (Figure 2) and graded as grade 2 . The purpose of the grading is standardization and monitoring of the treatments. There is no univer- 


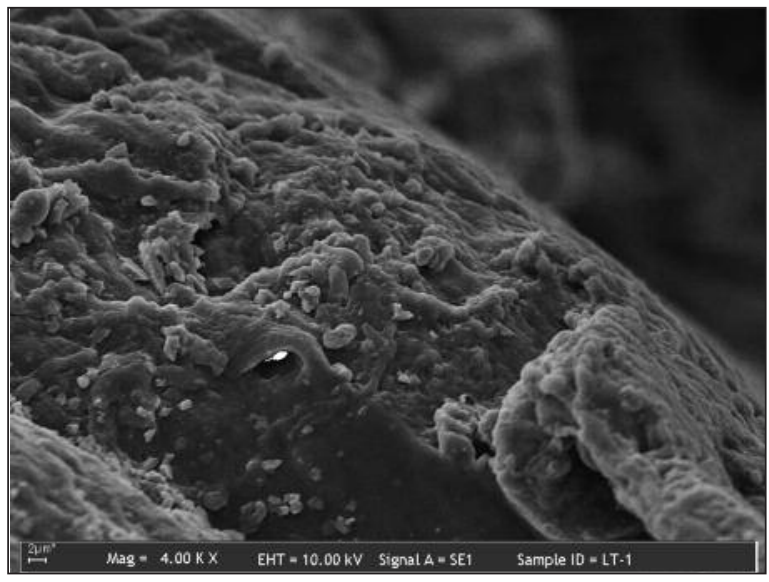

FIGURE 1: Light biofilm colonization of the number 2 specimen under $x 4000$ magnification.

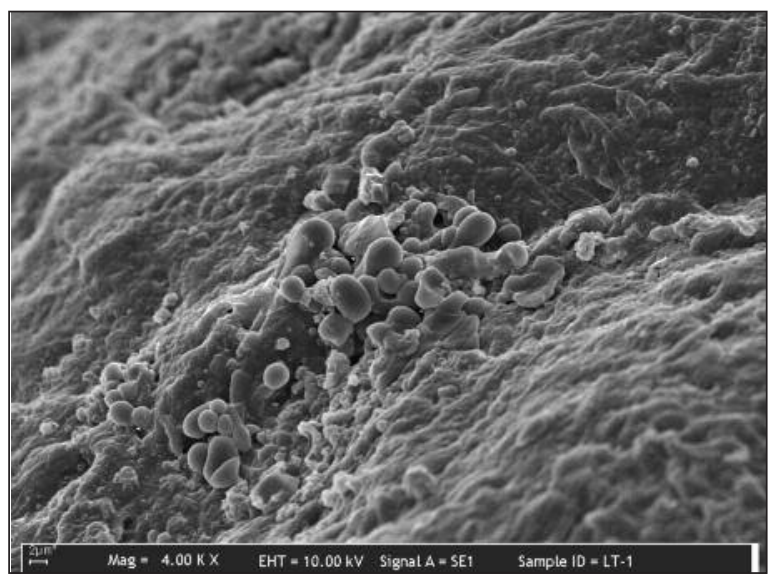

FIGURE 2: Dense biofilm colonization of the number 10 specimen under x4000 magnification.

sally accepted grading system, but we used a grading system which was used in the previous studies of one of our authors. ${ }^{7-9}$

Analysis of the data was done using SPSS (SPSS for Windows, version 11.5, SPSS, Chicago, IL). Continuous variables were expressed as mean \pm standard deviation (SD) and categorical variables were expressed as percentages.

\section{RESULTS}

We analyzed the lacrimal sac mucosal specimens of 3 male and 12 female patients. The mean age of

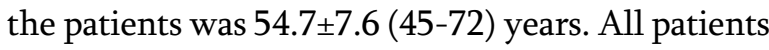
had unilateral dacryiostenosis. Duration of the symptoms was 6-36 months, with a mean duration of 18 months. Twelve of 14 specimens revealed bacterial biofilms under the SEM. There was dense colonization in 5 specimens, light colonization in the 7 specimens. Biofilm intensity was Grade 1 in $58.3 \%(\mathrm{n}=7)$ and Grade 2 in $41.6 \%(\mathrm{n}=5)$ of the patients. Due to the existence of thick surface deposits, one specimen could not be analyzed. Most of the bacterial colonization was composed of cocci. We detected pseudohyphae in 2 specimens in which bacterial colonization was also detected (Figure 3). Biofilms were detected on the lacrimal mucosa of 3 revision cases. Dense colonizations were seen in 2 cases and light colonization in 1 case. Among 14 cases, 4 had a history of acute dacryocystitis. Ten patients had no acute dacryosistitis history. Biofilms were detected in the $75 \%$ (3/4) of the patients with a history of acute dacryocystitis, and in $90 \%$ (9/10) of patients without any acute dacryocystitis history (Table 1).

\section{DISCUSSION}

Nasolacrimal duct obstructions generally develop due to recurrent infections and inflammations which lead to nasolacrimal duct stenosis. ${ }^{10}$ Chronic inflammation was detected in $76-95 \%$ of the histopathologic examinations of lacrimal sac specimens obtained during DCR in patients with epiphora. ${ }^{2,11,12}$ Triggering factors that lead to the development of chronic inflammation in the lacrimal sac are not known, but microbial colonization is thought to play a role. ${ }^{1,2,13}$ Bacterial growth was detected in the $84 \%$ of the samples in the study of Hartikainen et al. and in $42 \%$ in the study of DeAn-

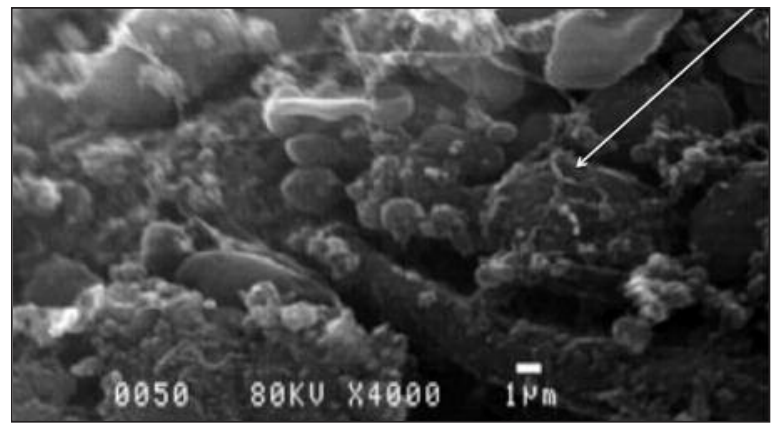

FIGURE 3: White arrow shows pseudohyphae formation besides bacterial colonization. 
TABLE 1: Presence of biofilms in patients with or without acute dacryocystitis.

\begin{tabular}{|lccc|}
\hline $\begin{array}{l}\text { Biofilm Presence } \\
\text { Acute dacryocystitis in history }\end{array}$ & Biofilm + & Biofilm - & Total \\
Acute dacryocystitis + & $n=3(75 \%)$ & $n=1(25 \%)$ & $n=4$ \\
Acute dacryocystitis - & $n=9(90 \%)$ & $n=1(10 \%)$ & $n=10$ \\
Total & $n=12$ & $n=2$ & $n=14$ \\
\hline
\end{tabular}

gelis et al. ${ }^{14,15}$ Culture negative results do not mean bacteria-free media. Centers for Disease Control and Prevention declared that biofilms were present in $65 \%$ of all bacterial infections. ${ }^{16}$ It is believed that $99 \%$ of all bacteria exist in biofilms. Only $1 \%$ lives in a free-floating state at any given time. ${ }^{3}$

The relationship between chronic infections and the biofilms has recently been discussed in the literature. Biofilm presence was documented in many infections, but its exact role in the process was not understood. $P$. aeruginosa, $S$. aureus, $S$. pneumonia and alpha hemolytic Streptococci are the organisms which can form biofilms and responsible for the acute and chronic dacryocystitis. ${ }^{14,17} \mathrm{We}$ isolated biofilm in $85.7 \%$ of the specimens derived from lacrimal sac mucosa, and this made us think about the causative role of biofilms in the etiology of dacryostenosis by its effect in the infection related inflammation.

We detected pseudohyphae in two of the lacrimal sac specimens in our study, which may indicate a fungal infection. Many medically important fungi like Candida, Aspergillus, Cryptococcus, Trichosporon, Coccidioides and Pneumocystis can produce biofilms. ${ }^{18}$ The presence of pseudohyphae is thought to be due to fungal colonization secondary the long-term antibiotic use.

Although we assume the presence of biofilm as a strong triggering factor leading to dacryostenosis, we also have to consider the possibility of biofilm development secondary to stasis and infections in the stenotic lacrimal duct. Tatar et al. suggested a grading system for the biofilm intensity in a study which examined biofilm formation on the tympanostomy tubes for the first time. ${ }^{7}$ In the literature, there are no other widely accepted grad- ing systems for this purpose. Since we do not have any idea whether the normal lacrimal sac mucosa contains biofilms or not, detection of biofilms in the lacrimal sac mucosa in patients with dacryostenosis cannot give an exact opinion about the role of biofilms in pathophysiology of lacrimal inflammation. Biofilms have been shown over the normal mucosa in the sinonasal cavity, and it is speculated that they can lead to an inflammatory reaction and may cause development of chronic sinusitis after reaching a critical intensity. ${ }^{19}$ This mechanism may be possible for the lacrimal system infections and stenosis. Biofilm intensity was Grade 1 in $58.3 \%$ and Grade 2 in $41.6 \%$ of the patients in our study. Clinical significance of the different biofilm intensities within the lacrimal sac could not be analyzed because of the insufficient number of the patients. The significance of the biofilm intensity should be analyzed with further studies with larger sample sizes and must be correlated with pathological findings.

Analysis of the biofilms can also be done with transmission electron microscopy (TEM) and confocal scanning laser microscopy (CSLM), besides scanning electron microscopy (SEM) ${ }^{20}$ SEM is a widely used technique to examine mucosal biofilms. We prefer SEM in our center for the investigation of biofilms, due to high experience of our anatomy department members about the biofilm examinations with SEM. There were 2 biofilm-free specimens in our study. Specimens obtained for biofilm analysis constitute a small part of the total lacrimal sac area. Absence of biofilm in that small part of the mucosa may not represent the entire mucosal surface. This may explain the absence of biofilms in these specimens.

To our knowledge, no studies in the literature have investigated biofilm formation in the lacrimal sac mucosa. This study seems to be the first, although further studies are needed for the clinical correlations of the biofilms.

\section{CONCLUSION}

Biofilms were identified in the samples obtained from the lacrimal sac mucosa during endoscopic 
dacryocystorinostomy procedure. This documentation appears to be the first evidence of demonstration of biofilms in the lacrimal sacs of patients with dacryostenosis. Further studies should be carried on about the role of biofilms in chronic in- fections, to determine whether it is the result or the cause of these infections. Overcoming biofilm formation would bring a great evolution for the solution of chronic infections like chronic dacryostenosis secondary to dacryocystitis.
1. Linberg JV, McCormick SA. Primary acquired nasolacrimal duct obstruction. A clinicopathologic report and biopsy technique. Ophthalmology 1986;93(8):1055-63.

2. Merkonidis C, Brewis C, Yung M, Nussbaumer $M$. Is routine biopsy of the lacrimal sac wall indicated at dacryocystorhinostomy? A prospective study and literature review. $\mathrm{Br} J$ Ophthalmol 2005;89(12):1589-91.

3. Ramadan HH, Sanclement JA, Thomas JG. Chronic rhinosinusitis and biofilms. Otolaryngol Head Neck Surg 2005;132(3):4147.

4. Costerton JW, Stewart PS, Greenberg EP. Bacterial biofilms: a common cause of persistent infections. Science 1999;284(5418):1318-22.

5. Borriello G, Werner E, Roe F, Kim AM, Ehrlich GD, Stewart PS. Oxygen limitation contributes to antibiotic tolerance of Pseudomonas aeruginosa in biofilms. Antimicrob Agents Chemother 2004;48(7):2659-64.

6. Post JC, Hiller NL, Nistico L, Stoodley P, Ehrlich GD. The role of biofilms in otolaryngologic infections: update 2007. Curr Opin Otolaryngol Head Neck Surg 2007;15(5):347-51.

7. Tatar EC, Unal FO, Tatar I, Celik HH, Gursel B. Investigation of surface changes in different types of ventilation tubes using scanning electron microscopy and correlation of findings

\section{REFERENCES}

with clinical follow-up. Int J Pediatr Otorhinolaryngol 2006;70(3):411-7.

8. Tatar EÇ, Tatar I, Ocal B, Korkmaz H, Saylam G, Ozdek A, et al. Prevalence of biofilms and their response to medical treatment in chronic rhinosinusitis without polyps. Otolaryngol Head Neck Surg 2012;146(4):669-75.

9. Saylam G, Tatar EC, Tatar I, Ozdek A, Korkmaz H. Association of adenoid surface biofilm formation and chronic otitis media with effusion. Arch Otolaryngol Head Neck Surg 2010; 136(6):550-5.

10. Onerci M. Dacryocystorhinostomy. Diagnosis and treatment of nasolacrimal canal obstructions. Rhinology 2002;40(2):49-65.

11. Bernardini FP, Moin M, Kersten RC, Reeves D, Kulwin DR. Routine histopathologic evaluation of the lacrimal sac during dacryocystorhinostomy: how useful is it? Ophthalmology 2002;109(7):1214-7; discussion 1217-8.

12. Salour $H$, Hatami MM, Parvin M, Ferdowsi AA, Abrishami M, Bagheri A. Clinicopathological study of lacrimal sac specimens obtained during DCR. Orbit 2010;29(5):250-3.

13. Robert C, Gregory L. Evaluation and manegement of tearing patient. American Academy of Ophtalmology. Section 7: Orbit, Eyelids, and Lacrimal System (Chap 14). San Francisco: Lifelong Comp; 2002. p.231-55.
14. DeAngelis D, Hurwitz J, Mazzulli T. The role of bacteriologic infection in the etiology of nasolacrimal duct obstruction. Can J Ophthalmol 2001;36(3):134-9.

15. Hartikainen J, Lehtonen OP, Saari KM. Bacteriology of lacrimal duct obstruction in adults. Br J Ophthalmol 1997;81(1):37-40.

16. Bezerra TF, Pádua FG, Ogawa Al, Gebrim EM, Saldiva PH, Voegels RL. Biofilm in chronic sinusitis with nasal polyps: pilot study. Braz J Otorhinolaryngol 2009;75(6):788-93.

17. Mills DM, Bodman MG, Meyer DR, Morton AD 3rd; ASOPRS Dacryocystitis Study Group. The microbiologic spectrum of dacryocystitis: a national study of acute versus chronic infection. Ophthal Plast Reconstr Surg 2007; 23(4):302-6.

18. Fanning S, Mitchell AP. Fungal biofilms. PLoS Pathog 2012;8(4):e1002585. doi: 10.1371/journal.ppat.1002585.

19. Sanderson AR, Leid JG, Hunsaker D. Bacterial biofilms on the sinus mucosa of human subjects with chronic rhinosinusitis. Laryngoscope 2006;116(7):1121-6.

20. Hall-Stoodley L, Stoodley P, Kathju S, Høiby $\mathrm{N}$, Moser C, Costerton JW, et al. Towards diagnostic guidelines for biofilm-associated infections. FEMS Immunol Med Microbiol 2012; 65(2):127-45. 